\title{
The Dose Reduction Factor Produced by Topically Applied Dimethyl Sulfoxide
}

The use of dimethyl sulfoxide (DMSO) as a radiation protective agent has been investigated in a variety of test objects. BRIDGES ${ }^{1}$ evaluated this chemical's action under aerated and anoxic conditions of irradiated bacteria (Pseudomonas sp.). Protection was found under both conditions, but to a greater extent in aerated cultures. AsHWoov-SMuTH ${ }^{2}$ reports radioprotective properties of DMSO when injected in mice. The protection of other sulfoxides such as methyl ethyl sulfoxide, tetramethylene sulfoxide was much smaller than that of DMSO. Some speculation was voiced at the recent International Conference on DMSO 1966 (sponsored by the New York Academy of Science) that the protective activity of this material may be associated with its relation to hydrogen bonding. Protection of tissue culture cells by DMSO against the effects of ionizing radiation was found by Vos and KaALEN ${ }^{3}$.

Despite the rather well documented high percutaneous absorption and solubility characteristics ${ }^{4,6}$ of this chemical all radiation protection studies involving mammals were done by injection (i.p.) or gastric intubation.

The relatively great DMSO penetration of the skin, low toxicity ${ }^{6}$ and ease of application without disturbing the integrity of the skin led us to the experimental procedure of topical application of DMSO in mice, instead of injection techniques. Reports of changes in the lens of dogs? and the warnings issued by the FDA in regard to this chemical have been taken into account and studies of possible occular pathology are under way. The amounts of DMSO described in RuBIN's paper, inducing refractory changes are in the order of $2.5-40 \mathrm{~g} / \mathrm{kg}$, which we estimate to be considerably in excess to the dosages absorbed through the skin of the mouse tail. Furthermore, no lens changes have been observed in rhesus monkeys receiving $5 \mathrm{~g} / \mathrm{kg} \mathrm{DMSO} /$ day for 100 days?.

Experimental methods. Only male CFW mice were used in our study. Their average age at the start of the experiments was $55 \pm 5$ days. Each animal was housed individually $(4 \times 5$ inch cubicles) in plastic cage units of 20 cubicles $^{8}$. Water and food was available ad libitum.

The tails of 10 mice from each cage unit were immersed in water for $10 \mathrm{~min}$ and those of the other 10 mice in anhydrous dimethyl sulfoxide (Matheson Scientific Company) for the same length of time. This treatment was given 15 min prior to X-ray exposure.

$\mathrm{X}$-irradiation was carried out at the following operating conditions. $225 \mathrm{KV}_{b}, 20 \mathrm{~mA}, 0.5 \mathrm{~mm} \mathrm{Cu}+1 \mathrm{~mm} \mathrm{Al}$ filtration; and an exposure rate of $10 \mathrm{R} / \mathrm{min}$. The target animal midline distance was $88.5 \mathrm{~cm}$. Uniformity of dose distribution over the entire cage unit was further improved by rotating the cage at $1 \mathrm{rpm}$.

The dosages employed for both animal groups (water or DMSO treated) were $700,800,850,900,950 \mathrm{R}$ resulting in exposure times of $70-95 \mathrm{~min}$. Unfortunately one group of animals treated with water and exposed to $700 \mathrm{R}$ had to be eliminated as they showed strong indications of bacterial infection. A total of 290 mice were used in our experimentation. Appropriate non-irradiated controls (treated with water or DMSO only) were kept also.

Results and discussion. In previous experiments" it was found that $5-10 \mathrm{~min}$ of immersion of the mouse tail in DMSO gave about maximum protection against radiation under the conditions described above. The statistically significanty difference between the water and DMSO treated animals was in the order of $P=0.05$ or better ${ }^{10}$. Survival curves of animal subjected to $\mathrm{X}$-ray dosages between $700-760 \mathrm{R}$ (total body) are shown in Figure 1. The $50 \%$ survival level for the water treated mice is reached on the fifteenth post-irradiation day, while in the DMSO group only about $40 \%$ had died at the thirtieth day.

This information together with the survival data obtained for the various X-ray dosages $(700-950 \mathrm{R})$ described before, is presented in Figure 2. It clearly shows the difference between the 2 treatment groups. The various survival percentages in this graph were gathered from the fifteenth post-irradiation day of each dose group. The dose reduction factor determined on the basis of the 2 curves in Figure 2 was 1.35 which corresponds very closely to the findings of AsHwooD-SMITH ${ }^{2}$ (DRF $=1.33$ ) using injection methods. This dose reduction factor of 1.35 compares rather well with that $\left(\mathrm{DRF}=1.45^{2}\right)$ obtained by the use of AET (S-2-aminoethyl-thiourouium bromide).
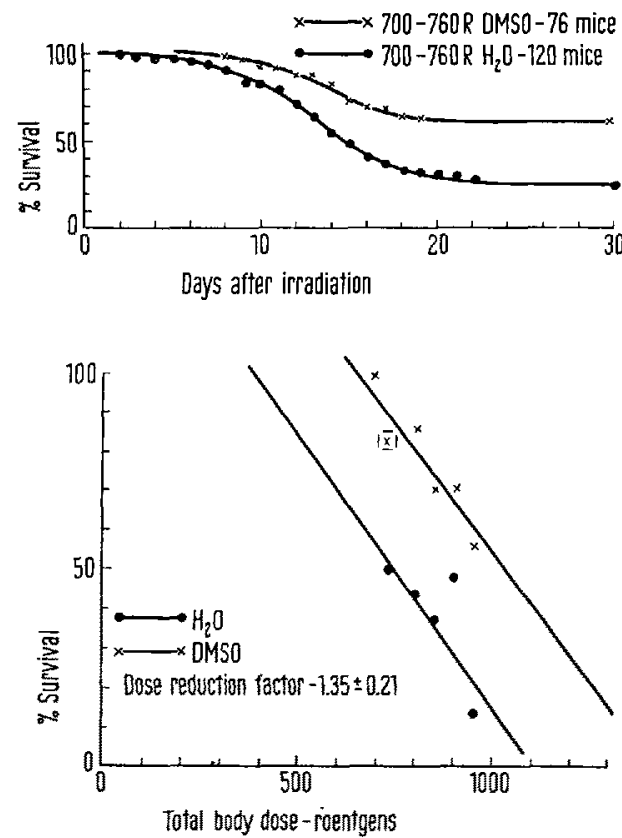

Fig. 1.

Fig. 2

Zusammentassung, Die früheren positiven Strahlenschutzmittel-Versuche mit ausserlich angewandtem Dimethyl-sulfoxid wurden mit verschieden grossen Strahlendosen erweitert, um den Strahlendosisreduktionsfaktor genauer $z u$ ermitteln. Es zeigte sich, dass dieser Faktor einer Grösse von 1.35 entspricht.

W. S. Moos and S. E. KIM

University of Illinois College of Medicine, Deparinent of Radiology, Chicago (Illinois 60680,USA), 24 November 1967.

I B. A. Brioges, Int. J. Radiat. Biol. 5, 101 (1962).

2 M. J. Ashwood-Smith, Int. J. Radiat. Biol. 3, 41 (1961).

a. Vos and M. C. Kallen, Int. J. Radiat. Biol. 5, 609 (1962).

${ }^{4}$ R. B. Stoughton and W. Fritch, Archs Derm. 90, 512 (1964).

* H. Rosenkranz, Z. Hadidian, H. Seay and M. M. Mason, Cancer Chemother. Rep. 37, 7 (1963).

${ }^{6}$ A. M. Kltgman, J. Am. med. Ass. 193, 140 (1965); 193, 151 (1965). 7 L. F. Rubin, Science 153, 83 (1966)

* W. S. Moos, J. B. Fuller and J. Plagge, Proc. Anim. Care Panel 17, 17 (1961)

W. S. Moos and S. E. Kim, Experientia 22, 814 (1966).

10 S. E. KıM, Radio-Protection of Topically Applied Dimethyl Sulfoxide on Mice (Thesis, University of Illinois 1966). 